\title{
Effects of Biochar and Chromolaena odorata Liquid Fertilizer Enriched with Sodium Bicarbonate on Soil and Muskmelon (Cucumis melo L.)
}

DOI: $10.18196 /$ pt.2020.108.7-14

\author{
Jamilah $^{1^{*}}$, Ari Yasman ${ }^{1}$, Elara Resigia ${ }^{2}$, Milda Ernita $^{1}$ \\ ${ }^{1}$ Study Program of Agrotechnology, Faculty of Agriculture, Universitas Tamansiswa Padang, Padang Utara, Padang 256138, Indonesia \\ ${ }^{2}$ Study Program of Agrotechnology, Faculty of Agriculture, Universitas Andalas, Pauh, Padang 50229, Indonesia \\ *Corresponding author, email: jamilahfatika@gmail.com
}

\begin{abstract}
Biochar is an organic material instantly made by burning wood into charcoal by pyrolysis, which can meet the high demand for an organic material that cannot be available in a short time. The study aimed to determine the effect of biochar and Chromolaena odorata liquid fertilizer (CLF) enriched with Sodium bicarbonate on soil pH and Muskmelon (Cucumis melo L.) productivity. The research was conducted from December to February 2019 at the field station of Tamansiswa University, Padang. The study was carried out in a factorial experiment with 2 treatment factors arranged in a Completely Randomized Design, consisting of three replications within treatments. The data obtained were analyzed using the F test at 5\%, followed by the Least Significant Difference (LSD) test at 5\%. The results showed that there was an interaction effect of Biochar and CLF application on reducing the soil pH. Among all treatments, the application of 2 t. Ha ${ }^{-1}$ biochar combined with $50 \mathrm{ml.L} \mathrm{L}^{-1} \mathrm{CLF}+\mathrm{O} \mathrm{g} \cdot \mathrm{L}^{-1}$ sodium bicarbonate resulted in the highest growth rate and yield of muskmelon in Ultisol soil.
\end{abstract}

Keywords: Biochar; C. odorata; Muskmelon; Sodium bicarbonate; Ultisol

\section{ABSTRAK}

Biochar merupakan bahan organik yang dibuat secara instan dengan membakar kayu menjadi arang secara pirolisis. Hal ini untuk menjawab tingginya kebutuhan bahan organik yang tidak bisa tersedia dalam waktu singkat. Percobaan ini bertujuan untuk mengetahui pengaruh Biochar dan pupuk cair $C$. odorata (PCC) yang diperkaya oleh Sodium bicarbonat terhadap sifat kimia tanah (pH), pertumbuhan dan hasil melon (Cucumis melo L.). Penelitian telah dilakukan pada bulan Desember- Februari 2019, di lahan percobaan Universitas Tamansiswa Padang. Percobaan dilaksanakan dalam bentuk Faktorial dengan 2 faktor perlakuan disusun dalam Rancangan Acak Lengkap, dan 3 ulangan. Data yang diperoleh dilakukan analisis menggunakan uji F taraf nyata 5\%, dan dilanjutkan dengan uji Beda Nyata Terkecil (BNT) taraf nyata 5\%. Dari hasil percobaan maka disimpulkan bahwa ada interaksi pemberian biochar dan PCC dalam menurunkan pH rizosfer tanaman melon secara nyata. Pemberian 50 ml.L.-1 PCC + 0 g.L.-1 Sodium Bicarbonate diringi dengan 2 t.Ha-1 biochar memberikan pertumbuhan dan hasil melon tertinggi mencapai 1,30 kg per buah per tanaman pada Ultisol.

Kata Kunci: Biochar; C. odorata; Melon; Sodium bicarbonat; Ultisol

\section{INTRODUCTION}

Fertilization is important in muskmelon cultivation. High soil organic matter content will result in high melon production as well. Ultisol is a mineral soil with organic matter content, alkaline saturation, and low pH (Soil Management, Fertilizer Use and Crop Nutrition, 2009). Jamilah \& Herman (2018) reported that the $\mathrm{pH}$ of Ultisol Lubuk Minturun, which was around 4.82, was classified as acidic. However, the procurement of soil organic matter requires a long time (Jamilah, 2010); (Ariyanto, Sickness, Project, \& Bisa, 2012); (Anonim, 2015); (Herman, Resigia, \& Syahrial, 2018). This problem can be overcome by producing biochar in the form of wood charcoal made by burning wood in a lack of oxygen (pyrolysis). Biochar is very important for soils, especially soils that are low in organic matter content (Gani, 2009). The use of biochar has been reported in a lot of research on various types of plants, both annual and perennial crops, resulting in the soil fertility improvement as well as the increase in plant growth rate and yield (Gani, 2009); (Mawardiana, Sufardi, \& Husen, 2013); (Sudjana, 2014). It is even known that the use of biochar can reduce the effects of chemical residues both from artificial fertilizers and excessive use of pesticides, thereby providing health to the environment (Herman et al., 2018).

The use of liquid organic fertilizer is so im- 
portant that the use of chemical fertilizers can be reduced slowly. The use of biochar through the soil and organic liquid fertilizer through plant leaves is considered ideal in a fertilization method. Organic liquid fertilizer derived from C. odorata raw material has been proven to be able to reduce the use of artificial fertilizers by $25-50 \%$ in various food crops and vegetables (Jamilah, 2010); (Jamilah, 2015); (Jamilah, 2016); (Jamilah, 2018). The effectiveness of C. odorata liquid fertilizer (CLF) is also possible to be increased by enriching it with sodium bicarbonate. Sodium bicarbonate is already popular abroad to be applied in various crops and places with specific purposes. The provision of small amounts of sodium bicarbonate can even increase the amount of chlorophyll and photosynthetic activity. The application of sodium bicarbonate was also able to increase the sweet taste of tomatoes (Bie, Ito, \& Shinohara 2004; Campbell \& Nishio 2000). The effect of sodium bicarbonate is unknown if it is used to enrich the nutrient of CLF on increasing the growth and yield of melon plants. The purpose of this study was to determine the effect of biochar and CLF enriched with sodium bicarbonate on soil chemical properties $(\mathrm{pH})$ as well as on the growth and yield of Muskmelons (Cucumis melo L.)

\section{MATERIALS AND METHODS}

The pot experiments were carried out in the field of Faculty of Agriculture, Tamansiswa University, located in Ampang Padang, about $5 \mathrm{~km}$ from campus at $20 \mathrm{~m}$ above sea level. The materials and tools used were Ceramic trademark Muskmelon seeds, skyrocket. Fertilizers used were biochar from wood charcoal made by pyrolysis combustion minus oxygen, C. odorata liquid fertilizer (CLF) and sodium bicarbonate. Ultisol was used as planting media, which was taken from Lubuk Minturun.

The experiment was carried out in a completely randomized factorial design with 2 factors. The first factor was was the administration of biochar at a dose of $0,2 \mathrm{tha}^{-1}$, and $4 \mathrm{tha}$. The second factor was the administration of CLF enriched with sodium bicarbonate at a concentration of $0 \mathrm{ml} \mathrm{L}^{-1}, 50$ $\mathrm{ml} \mathrm{L}{ }^{-1} \mathrm{CLF}+0 \mathrm{mg} \mathrm{L}^{-1}$ sodium bicarbonate, and 50 $\mathrm{ml} \mathrm{L}{ }^{-1} \mathrm{CLF}+2 \mathrm{~g} \mathrm{~L}^{-1}$ sodium bicarbonate, replicated 3 times to obtain 9 treatment combinations and 27 experimental units. Each treatment was assigned 3 sample observations, resulting in 81 pots.

The fine Ultisol was sifted through a diameter of $2 \mathrm{~mm}$ and inserted into a pot with an average weight of $10 \mathrm{~kg}$. PONSKA basic fertilizer (15-1515) was given at $400 \mathrm{~kg} \mathrm{ha}^{-1}$. Fertilizer and biochar measurements were based on a plant population of 40000 per hectare. Biochar was produced by burning wood into charcoal that was then tightly closed before forming ash. After chilling, biochar was mashed and weighed according to the treatments. Biochar was incubated for a week by stirring it evenly on the planting medium and keeping it in a tightly closed black plastic. Liquid fertilizer was made from a mixture of C. odorata plants added with coco fiber, manure, cow urine, coconut water, local microorganisms (LOM), and banana stems. The ingredients were decomposed by keeping it in a tightly closed place for a month and then put into a fermentation container with a composition of $90 \%$ that was then added with LOM and cow urine until 100\%. The next step was adding water with the same ratio as the ingredients to be fermented for 4 months, then filtered and applied as treatments.

Melon seeds were sown on the seedbed and then transferred to each pot after 2 weeks. Liquid fertilizer was applied to the plants every week until the 6 th week. Fertilizers and biochar as treatments were given when transplanting from seedling media to pots. The observed variables included soil $\mathrm{pH}$ (H2O) and plant length at 21 and 64 days after planting. The measurement of plant length was carried out starting from the base stems to the growing point. The number of branches was determined by 
counting all the branches of plants on the primary stem. The weight of fresh crop stover was observed by weighing all fresh stover without melons (fruits). The weight and circumference of the fruit were also determined. The soil $\mathrm{pH}$ was determined by using the $\mathrm{pH}$ of the electrode of the soil samples taken from the rhizosphere of Melon roots that had been harvested and then air-dried. As much as $10 \mathrm{~g}$ of soils were dissolved in $25 \mathrm{ml}$ of water $(\mathrm{pH}=6.83)$ with a ratio $(1: 2.5)$, then shaken +15 minutes, then precipitated 3 minutes and measured for its $\mathrm{pH}$.

Observational data were analyzed statistically using F-tests at 5\%. If the treatments showed a significant effect, further tests were carried out using an LSD test at 5\%.

\section{RESULTS AND DISCUSSION}

There was an interaction effect of biochar and CLF on the chemical reaction of the soil $(\mathrm{pH})$ of the rhizosphere of the melon plant. Data were analyzed chemically and subsequently analyzed statistically using F-tests at 5\%. Further test was performed using the LSD test (Table 1).

Combined with biochar application at 0 and 2 $\mathrm{t} \mathrm{ha}^{-1}$, the administration of CLF reduced the $\mathrm{pH}$ of Ultisol soils from 4.33 to 3.99 (7.8\%) and from 4.04 to 3.77 (6.68\%), respectively. Meanwhile, the increasing dose of biochar without CLF administration significantly decreased the soil $\mathrm{pH}$ in the rhizosphere of melon from 4.33 to 3.87 is (10.62\%). This result was also proven by Tambunan, Siswanto, \& Handayanto (2014), reporting that the administration of biochar had the effect on reducing soil $\mathrm{pH}$ in corn from 6.93 to 6.23 (10\%) at 49 days after planting. Combined with $50 \mathrm{ml}$ of $\mathrm{L}^{-1} \mathrm{CLF}+0 \mathrm{gL}^{-1}$ sodium bicarbonate, the increasing dose of biochar did not significantly reduce soil $\mathrm{pH}$, while when combined with $50 \mathrm{ml} \mathrm{L}^{-1}$ CLF $+2 \mathrm{~g} \mathrm{~L}^{-1}$ sodium bicarbonate, it significantly reduced soil $\mathrm{pH}$ from 3.99 to 3.66 (8.27\%). The administration of CLF also showed an effect on reducing the soil $\mathrm{pH}$ in melon rhizosphere. The $\mathrm{pH}$ of CLF was adjusted to 8.6 before it was sprayed to the plants. This result showed that there was a metabolic effect contributing more organic acids compared to the plants that were not sprayed with CLF. Reports by (Gani, 2009); (Tambunan et al., 2014); (Nurida, 2014); (Zaylany, 2017) and (Hasibuan, 2017) proved that the biochar of various agricultural waste materials could increase soil $\mathrm{pH}$. Bargmann, Rillig, Buss, Kruse, \& Kuecke (2013) proved that high-dose biochar, in general, reduced the germination rate of Barley plants, while the low dose of biochar increased their development. Lehmann et al. (2011) proved that Biochar did not have a negative effect on plant roots and soil biota, nor did it have a positive impact on the chemical properties of Ultisols.

Table 1. Effect of Biochar and CLF enriched with sodium bicarbonate on the pH of the rhizosphere of muskmelon at 64 DAP (days after planting)

\begin{tabular}{|c|c|c|c|c|}
\hline \multirow{2}{*}{$\begin{array}{l}\text { Treatments } \\
\text { Biochar }\end{array}$} & \multicolumn{3}{|c|}{ Provision of CLF + Sodium Bicarbonate } & \multirow{2}{*}{ Average } \\
\hline & $0 \mathrm{ml} \mathrm{L}^{-1}+0 \mathrm{~g} \mathrm{~L}^{-1}$ & $50 \mathrm{ml} \mathrm{L}^{-1}+0 \mathrm{~g} \mathrm{~L}^{-1}$ & $50 \mathrm{ml} \mathrm{L}^{-1}+2 \mathrm{~g} \mathrm{~L}^{-1}$ & \\
\hline \multicolumn{5}{|c|}{$\mathrm{pH}\left(\mathrm{H}_{2} \mathrm{O}\right)$} \\
\hline 0 t ha $^{-1}$ & 4.33 aA & $3.79 \mathrm{aB}$ & $3.99 \quad a B$ & $4.03 a$ \\
\hline 2 t ha $^{-1}$ & $4.04 \mathrm{abA}$ & $3.72 \mathrm{aB}$ & $3.77 \mathrm{abAB}$ & $3.84 \mathrm{~b}$ \\
\hline 4 t ha $^{-1}$ & 3.87 bA & $3.90 \mathrm{aA}$ & $3.66 \mathrm{bA}$ & $3.81 \mathrm{~b}$ \\
\hline Average & $4.08 \mathrm{~A}$ & $3.80 \mathrm{~B}$ & 3.80 & \\
\hline CV (\%) & 4.67 & & & \\
\hline
\end{tabular}

Remarks: Means followed by the same uppercase letters in the same row and means followed by the same lowercase letters in the same column are not significantly different according to the LSD test at $5 \%$. 
The application of Biochar and CLF to several agronomic parameters of melon plants is presented in Table 2. There was an interaction effect of the biochar and CLF on the plant length at flowering stage and number of branches.

In general, the administration of CLF significantly affected the plant length at harvest and the fresh stover weight. The longer the plant, the heavier the fresh stover, in which the highest value was observed in the treatment of $50 \mathrm{ml} \mathrm{L}^{-1}$ CLF + $0 \mathrm{~g}$ sodium bicarbonate. The application of biochar showed no significant effect on the plant length at harvest.
The application of $2 \mathrm{t} \mathrm{ha}^{-1}$ biochar produced plant length at flowering that was not significantly different from the length of plants are given $4 \mathrm{t}$ ha ${ }^{-1}$ biochar. This result was due to soil $\mathrm{pH}$ (Table 1) that was already so low that nutrients were not optimally available for melon plants. (Jennifer \& Morgan, 2013); (Oosterhuis, 2009) explains that $\mathrm{pH}$ greatly influences the availability of nutrients in the soil. In the $\mathrm{pH}$ range of 3-4, in general, some nutrients such as $\mathrm{Ca}, \mathrm{Mg}, \mathrm{K}$, and Nitrogen will be difficult to be absorbed by plants., but microelements such as Fe and Mn will be highly available. Plants that were given CLF $+0 \mathrm{~g}$ Sodium bicarbon-

Table 2. Effects of biochar and CLF enriched with sodium bicarbonate on muskmelon growth

\begin{tabular}{|c|c|c|c|c|}
\hline \multirow{2}{*}{$\begin{array}{l}\text { Treatments } \\
\text { Biochar }\end{array}$} & \multicolumn{3}{|c|}{ Provision of CLF + Sodium Bicarbonate } & \multirow{2}{*}{ Average } \\
\hline & $0 \mathrm{ml} \mathrm{L}^{-1}+0 \mathrm{~g} \mathrm{~L}^{-1}$ & $50 \mathrm{ml} \mathrm{L}^{-1}+0 \mathrm{~g} \mathrm{~L}^{-1}$ & $50 \mathrm{ml} \mathrm{L}^{-1}+2 \mathrm{~g} \mathrm{~L}^{-1}$ & \\
\hline \multicolumn{5}{|c|}{ Plant length at 21 days after the first flower $(\mathrm{cm})$} \\
\hline 0 t ha $^{-1}$ & 26.77 aA & 30.85 aA & $20.27 \mathrm{bB}$ & 25.96 \\
\hline $2 \mathrm{tha}^{-1}$ & $27.52 \mathrm{abA}$ & $28.17 \mathrm{abA}$ & $28.60 \mathrm{aA}$ & 28.09 \\
\hline $4 \mathrm{t} \mathrm{ha}^{-1}$ & $22.75 \mathrm{bA}$ & $25.84 \mathrm{bA}$ & $26.50 \mathrm{aA}$ & 25.03 \\
\hline Average & 25.68 & 28.29 & 25.12 & \\
\hline CV (\%) & 13.18 & & & \\
\hline \multicolumn{5}{|c|}{ Plant length at 64 days after the first flower $(\mathrm{cm})$} \\
\hline $0 \mathrm{t} \mathrm{ha}^{-1}$ & 98.58 & 147.43 & 122.93 & 122.98 \\
\hline $2 \mathrm{t} \mathrm{ha}^{-1}$ & 110.26 & 115.23 & 114.38 & 113.29 \\
\hline $4 \mathrm{t} \mathrm{ha}^{-1}$ & 97.37 & 113.92 & 114.61 & 108.63 \\
\hline Average & $102.07 \mathrm{~B}$ & $125.53 \mathrm{~A}$ & $117.31 A B$ & \\
\hline CV (\%) & 13.62 & & & \\
\hline \multicolumn{5}{|c|}{ Number of branches (strands) } \\
\hline 0 t ha $^{-1}$ & $6.00 \mathrm{aB}$ & $7.33 \mathrm{aA}$ & $6.50 \mathrm{bAB}$ & 6.61 \\
\hline 2 t ha $^{-1}$ & $6.00 \mathrm{aB}$ & $7.83 \mathrm{aA}$ & $7.00 \mathrm{abAB}$ & 6.94 \\
\hline $4 \mathrm{t} \mathrm{ha}^{-1}$ & $6.83 \mathrm{aB}$ & $6.00 \mathrm{bB}$ & $8.00 \quad \mathrm{aA}$ & 6.94 \\
\hline Average & 6.28 & 7.06 & 7.17 & \\
\hline CV (\%) & 8.79 & & & \\
\hline \multicolumn{5}{|c|}{ Fresh stover weight of melon plant (kg) } \\
\hline $0 \mathrm{t} \mathrm{ha}^{-1}$ & 0.21 & 0.27 & 0.28 & $0.25 b$ \\
\hline $2 \mathrm{t} \mathrm{ha}^{-1}$ & 0.22 & 0.35 & 0.36 & $0.31 \mathrm{a}$ \\
\hline $4 \mathrm{t} \mathrm{ha}^{-1}$ & 0.21 & 0.40 & 0.36 & $0.32 \mathrm{a}$ \\
\hline Average & $0.21 \mathrm{~B}$ & $0.34 \mathrm{~A}$ & $0.33 \mathrm{~A}$ & \\
\hline CV (\%) & 16.83 & & & \\
\hline
\end{tabular}

Remarks: Means followed by the same uppercase letters in the same row and means followed by the same lowercase letters in the same column are not significantly different according to the LSD test at $5 \%$. 

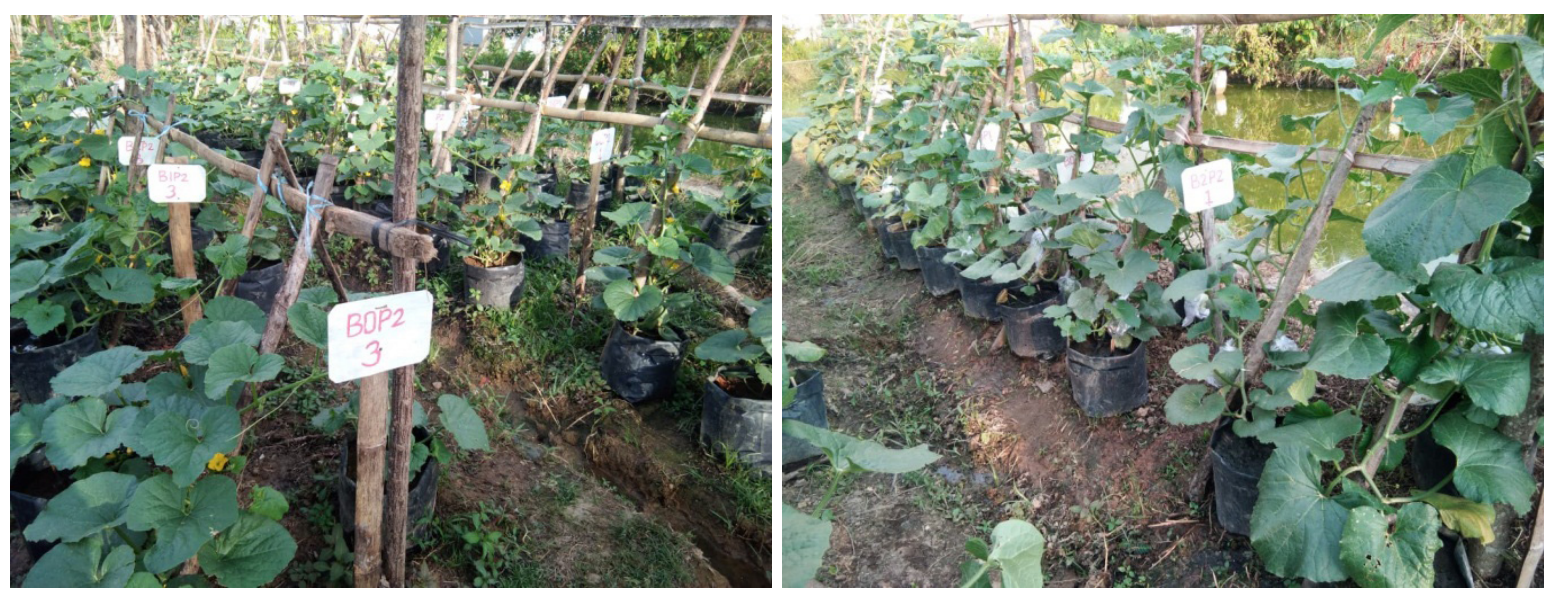

Figure 1. Performance of muskmelon as affected by BOP2 treatment

(0 t ha-1 Biochar $+50 \mathrm{ml} \mathrm{L}^{-1}$ CLF enriched $2 \mathrm{~g} \mathrm{~L}^{-1}$ sodium bicarbonate), and several other samples at 40 days after planting
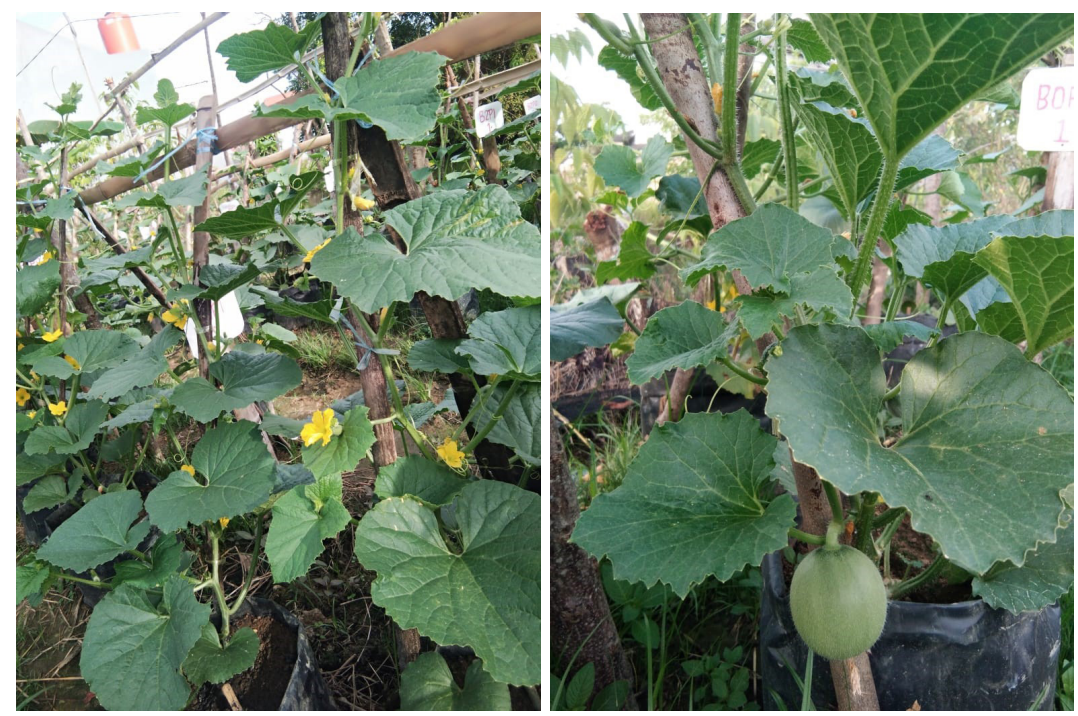

Figure 2. Performance of muskmelon plants when producing fruit (generative phase)

ate produced the longest plant length compared to when the plants were also given biochar 2-4 t ha-1.

The number of branches also increased significantly when the plants were given CLF, either without sodium bicarbonate enriched or with sodium bicarbonate. There was an effect of sodium bicarbonate on improving the quality of liquid fertilizers and biochar, thereby producing the highest number of branches. A lot of branches will produce high vegetation as well so that it will provide large parts performing high photosynthesis activity. Consequently, higher photosynthates are produced, which will affect the formation of fruit and other organs. The stiver weight of melon plants was the highest when the plants were fertilized with $50 \mathrm{ml} \mathrm{L}^{-1}$ of CLF. The effect of the highest dose of biochar ( $4 \mathrm{t} \mathrm{ha}^{-1}$ ) was not significantly different from the effect of the dose of $2 \mathrm{tha}^{-1}$ on the fresh stover weight of melon plants. It turns out that the more branches produced will produce higher fresh stover weight. Plants that get enough nutrients from the application of CLF are producing high fresh stover weight as well.

According to Figure 1, plants grew normally at 40 days after planting because they were still young. Even though the soil $\mathrm{pH}$ was around 3-4, the growth of melons was still in the normal category. At that age, necrotic or drought symptoms did not 
Table 3. Effects of Biochar and CLF enriched with sodium bicarbonate on the muskmelon yield

\begin{tabular}{|c|c|c|c|c|}
\hline \multirow{2}{*}{$\begin{array}{l}\text { Treatments } \\
\text { Biochar }\end{array}$} & \multicolumn{3}{|c|}{ Provision of CLF + Sodium Bicarbonate } & \multirow{2}{*}{ Average } \\
\hline & $0 \mathrm{ml} \mathrm{L}^{-1}+0 \mathrm{~g} \mathrm{~L}^{-1}$ & $50 \mathrm{ml} \mathrm{L}^{-1}+0 \mathrm{~g} \mathrm{~L}^{-1}$ & $50 \mathrm{ml} \mathrm{L}^{-1}+2 \mathrm{~g} \mathrm{~L}^{-1}$ & \\
\hline \multicolumn{5}{|c|}{ Fruit circumference $(\mathrm{cm})$} \\
\hline $0 \mathrm{t} \mathrm{ha}^{-1}$ & 33.67 & 41.67 & 41.33 & 38.89 \\
\hline $2 \mathrm{tha}^{-1}$ & 36.33 & 40.33 & 42.17 & 39.61 \\
\hline $4 \mathrm{t} \mathrm{ha}^{-1}$ & 38.50 & 39.00 & 42.17 & 39.89 \\
\hline Average & $36.17 \mathrm{~B}$ & $40.33 \mathrm{~A}$ & $41.89 \mathrm{~A}$ & \\
\hline CV (\%) & 8.23 & & & \\
\hline \multicolumn{5}{|c|}{ Fruit weight (kg) } \\
\hline 0 t ha $^{-1}$ & $0.54 \mathrm{bA}$ & $1.15 \mathrm{bA}$ & $1.07 \mathrm{bA}$ & 0.92 \\
\hline $2 \mathrm{tha}^{-1}$ & $0.77 \mathrm{aB}$ & $1.30 \mathrm{aA}$ & $1.19 \mathrm{aAB}$ & 1.09 \\
\hline $4 \mathrm{t} \mathrm{ha}^{-1}$ & $0.82 \mathrm{aA}$ & $1.18 \mathrm{bA}$ & $1.19 \mathrm{aA}$ & 1.06 \\
\hline Average & $0.71 \mathrm{~B}$ & $1.21 \mathrm{~A}$ & $1.15 \mathrm{~A}$ & \\
\hline CV (\%) & 6.67 & & & \\
\hline
\end{tabular}

Remarks: Means followed by the same uppercase letters in the same row and means followed by the same lowercase letters in the same column are not significantly different according to the LSD test at 5\%.

appear, indicating the plants got a balanced nutri- plants getting good fertilizer treatment from either ent. However, when compared with melons planted in soils that have an ideal $\mathrm{pH}$ for melons between 6-6.5, the plant height and plant performance were still not optimal (Lena, Jamilah, \& Haryoko, 2018).

Figure 3 shows that plants given $4 \mathrm{t} \mathrm{ha}^{-1}$ biochar followed by CLF produced leafy leaves that were very healthy without necrotic symptoms. Meanwhile, the application of $4 \mathrm{tha}^{-1}$ biochar combined with CLF enriched with $2 \mathrm{~g} \mathrm{~L}^{-1}$ sodium bicarbonate showed some necrotic spots. Damage to these plants does not affect the length of the plant or the number of branches of muskmelon plants but will affect the fresh stover weight. In this observation, plants were harvested for the next 10 days. It was proven that the fresh stover weight of the plant treated with BOPO was indeed the lowest compared to the plants with other treatments (Table 2 ), showing dried and necrotic leaves). This result is due to the fact that plant nutrients provided from the soil and basic fertilizers are inadequate to maintain plant growth and health.

Necrotic symptoms can be caused by plants lacking nutrients or due to pest attacks. The leaves attacked are specifically dominant in the plants that get control treatment (BOPO). However, biochar or CLF produced healthy and fresh green leaves. These healthy leaves are very supportive in photosynthetic activity. Photosynthesis going well will be able to result optimal photosynthates, so as to increase the size and weight of melons.

Fresh stover weight of muskmelon plants increased by $61.90 \%$ in plants given CLF compared to the fresh stover weight of plants without CLF. There was no progressive response from plants given CLF with or without sodium bicarbonate. This result showed that sodium bicarbonate was not able to significantly improve nutrient uptake in melon plants.

The circumference and weight of melon fruit were more influenced by the administration of CLF than biochar administration (Figure 2 and Table 3). The enrichment of sodium bicarbonate in CLF was proven to increase the growth and yield of melons but was not significantly different compared to those only given CLF. Fruit circumference increased by $11.5 \%$ in plants given CLF compared to the fruits that were not given CLF. The circumference of melons ranged from 33 to 42 $\mathrm{cm}$, similar to what was reported by Lena Ananda Putri, Jamilah, (2018), which was $32-42 \mathrm{~cm}$, with 

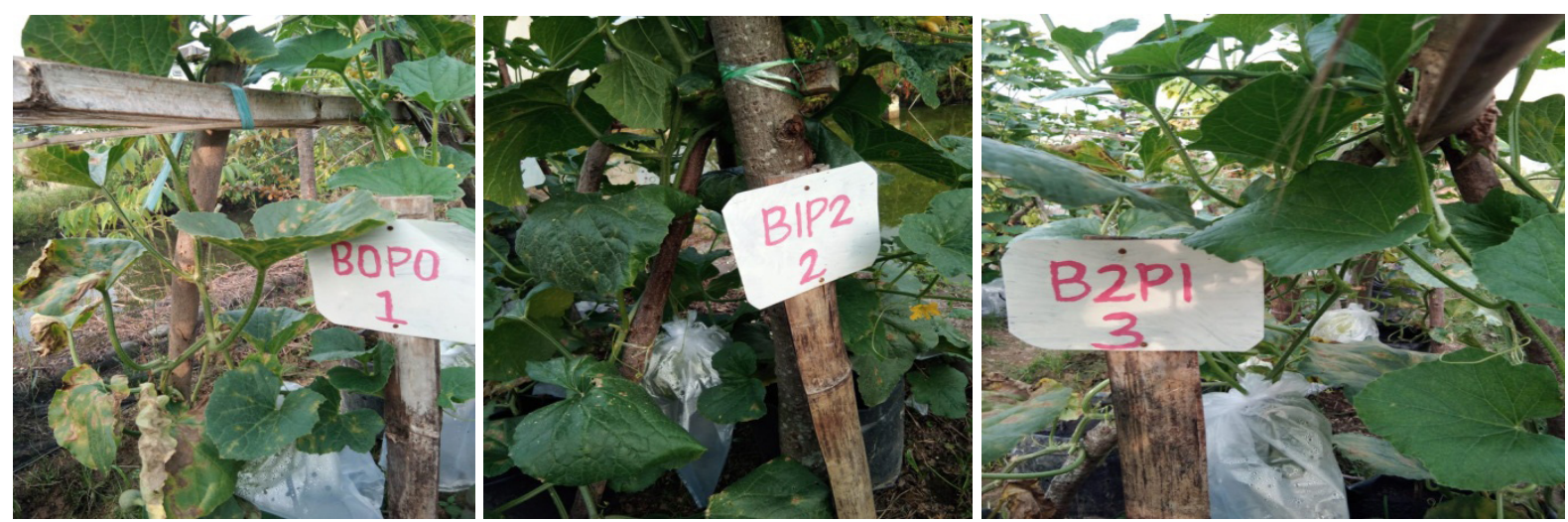

Figure 3. Plants aged 62 DAP, BOPO (control) dried from the edge of the leaf, B1P2 (2 t ha $a^{-1}$ Biochar $+50 \mathrm{ml} \mathrm{L}^{-1} \mathrm{CLF}_{\text {enriched }}$ $2 \mathrm{~g} \mathrm{~L}^{-1}$ sodium bicarbonate) and B2P1 ( $4 \mathrm{t} \mathrm{ha}^{-1}$ Biochar $+50 \mathrm{ml} \mathrm{L}^{-1} \mathrm{CLF}$ ) looking green without significant brown necrotic
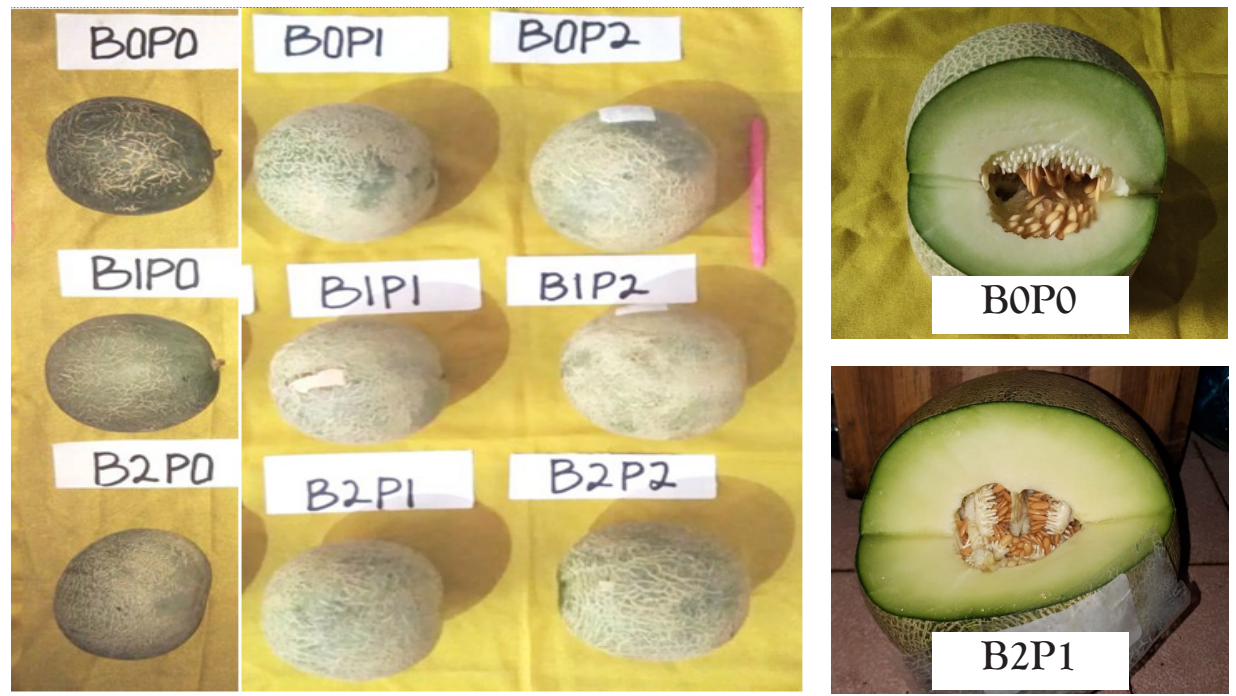

Figure 4. The appearance of muskmelon fruits (left) and muskmelon fruits that have been opened (right)

the highest weight of melons per fruit of $1.33 \mathrm{~kg}$.

There was an interaction effect of the biochar and liquid fertilizer on the weight of the muskmelon fruit (Table 3, Figure 2). The highest fruit weight was $1.30 \mathrm{~kg}$ per fruit, observed in plants given $2 \mathrm{t} \mathrm{ha}^{-1}$ biochar combined with $50 \mathrm{ml} \mathrm{L}^{-1}$ CLF every week, while the lowest fruit weight was observed in plants with control treatment. Jančík, Homolka, Čermák, \& Lád (2008) mention that the weight of muskmelons can be up to $2.8 \mathrm{~kg}$ per fruit, which means that the muskmelon fruit in this study can still have a chance to increase by up to two times. This result proved that Ultisol was still not optimally able to provide nutrients for muskmelon plants, even though biochar and CLF were also given. The application of biochar and CLF enriched with sodium bicarbonate was proven to improve the growth of muskmelon. The fruit weight of muskmelon given $50 \mathrm{ml} \mathrm{L}^{-1}$ CLF increased by $70.42 \%$ compared to the fruit weight of muskmelon that were not given liquid fertilizer. This result showed that Ultisol, which was not given both, did not help increase the growth and yield of Muskmelons. From this condition, it is clear that melon cultivation really needs fertile soil.

Compared with the results of the study by Lena Ananda Putri, Jamilah (2018), at the same $50 \mathrm{ml}$ $\mathrm{L}^{-1} \mathrm{CLF}$ treatment, the yield in this study was still lower at around $0.94 \mathrm{~kg}$ per fruit. At the same dose, the fruit weight of the muskmelon was higher when $2 \mathrm{t} \mathrm{ha}^{-1}$ biochar was also given, reaching $1.3 \mathrm{~kg}$ per fruit. The high fruit weight of melon was also due 
to the influence of the vegetation growing better due to higher number of branches (Table 2 and Figure 4). The plants obtained good nutrition, including balanced nitrogen, phosphorus, and potassium. The microelement was also obtained by the plants from CLF because the fertilizer also contains a complete microelement.

\section{CONCLUSIONS}

There was a significant interaction effect of biochar and CLF on reducing the soil $\mathrm{pH}$ in the rhizosphere of muskmelon plants. Fruit circumference and fruit weight increased by $11.5 \%$ and 70.42\%, respectively, when given CLF. Among all treatments, the application of $2 \mathrm{t} \cdot \mathrm{Ha}^{-1}$ biochar combined with $50 \mathrm{ml}$ of L ${ }^{-1} \mathrm{CLF}+0 \mathrm{~g} \mathrm{~L}^{-1}$ sodium bicarbonate resulted in the highest growth and yield of muskmelons, reaching $1.30 \mathrm{~kg}$ per fruit per plant.

\section{ACKNOWLEDGMENTS}

Thank you to the Chair of the Study Program and LPPM who facilitated this research activity. Thank you to the Chancellor for providing facilities and field facilities so that the research ran smoothly from preparation to completion.

\section{REFERENCES}

Anonim. (2015). Peranan bahan organik terhadap kesuburan tanah. Statewide Agricultural Land Use Baseline 2015, 1. https://doi. org/10.1017/CB09781107415324.004

Ariyanto, D. P., Sickness, S., Project, M., \& Bisa, ÆE. (2012). Pupuk Dan Pemupukan. 1-9.

Bargmann, l., Rillig, M. C., Buss, W., Kruse, A., \& Kuecke, M. (2013). Hydrochar and biochar effects on germination of spring barley. Journal of Agronomy and Crop Science, 199(5), 360-373. https://doi.org/10.1111/jac.12024

Bie, Z., Ito, T., \& Shinohara, Y. (2004). Effects of sodium sulfate and sodium bicarbonate on the growth, gas exchange and mineral composition of lettuce. Scientia Horticulturae, 99(3-4), 215-224. https://doi.org/10.1016/S0304-4238(03)00106-7

Campbell, S. A., \& Nishio, J. N. (2000). Iron deficiency studies of sugar beet using an improved sodium bicarbonate-buffered hydroponic growth system. Journal of Plant Nutrition, 23(6), 741-757. https://doi.org/10.1080/01904160009382056
Gani, A. (2009). Potensi Arang Hayati “ Biochar " sebagai Komponen Teknologi Perbaikan Produktivitas Lahan Pertanian. Iptek Tanaman Pangan, 4(1), 33-48.

Hasibuan, I. (2017). Konservasi Lahan Marjinal Dengan Aplikasi Biochar Plus. J. Agroqua, 15(2), 43-50.

Herman, W., Resigia, E., \& Syahrial. (2018). Formulasi biochar dan kompos Titonia terhadap ketersediaan hara tanah Ordo Ultisol. Agrotekma, 2(2), 152-158.

Jamilah. (2010). Serapan hara dan hasil Jagung yang Diaplikasi Pupuk Buatan dan KOmpos Kronobio. Agrivigor, 10 (1), 10-17. Jamilah. (2015). judul invensi: Produk pupuk organik cair C. odorata dan sabut kelapa yang diperkaya dengan mikroorganisme lokal. Padang: HKI.3-HI.05.01.03.2016/06641.

Jamilah. (2016). Pengaruh Pupuk Organik Cair Asal C. odorata Terhadap Serapan Hara Kalium Dan Hasil Padi Ladang. Jurnal Bibiet, ISSN 2502-0951, 1(1), 17-26. https://doi.org/http:// dx.doi.org/10.22216/jbbt.v1i1.258

Jamilah. (2018). Budidaya Padi Yang Dipangkas Secara Periodic Dan Diberi Pupuk Kompos Chromolaena odorata Dan Analisis. Jurnal ILmiah Pertanian, 14(9), 35-45.

Jamilah, \& Herman, W. (2018). karakteristik sifat fisika dan kimia tanah yang mendukung ketahanan pangan di Sumatera Barat. Padang.

Jančík, F., Homolka, P., Čermák, B., \& Lád, F. (2008). Determination of indigestible neutral detergent fibre contents of grasses and its prediction from chemical composition. Czech Journal of Animal Science, 53(3), 128-135.

Jennifer, \& Morgan, B. (2013). Plant-Soil Interactions : Nutrient Uptake Changes in root architecture, induction of root-based transport systems and associations with beneficial soil microorganisms allow plants to maintain optimal nutrient content in the face of changing soil environm. 4, 2-7.

Lehmann, J., Rillig, M. C., Thies, J., Masiello, C. A., Hockaday, W. C., \& Crowley, D. (2011). Biochar effects on soil biota - A review. Soil Biology and Biochemistry, 43(9), 1812-1836. https://doi. org/10.1016/j.soilbio.2011.04.022

Lena, A. P., Jamilah, \& Haryoko, W. (2018). Pengaruh Pupuk Organik Cair Dan Trichoderma Sp Terhadap Pertumbuhan Dan Hasil Melon (Cucumis melo). J. Bibiet, 3(1), 17-24.

Mawardiana, Sufardi, \& Husen, E. (2013). Pengaruh residu biochar dan pemupukan npk terhadap sifat kimia tanah dan pertumbuhan serta hasil tanaman padi musim tanam ketiga. Jurnal Konserasi Sumberdaya Lahan, 1(1), 16-23.

Nurida, N. L. (2014). Potensi Pemanfaatan Biochar untuk Rehabilitasi Lahan Kering di Indonesia. Jurnal Sumberdaya Lahan, 57-68.

Oosterhuis, D. (2009). Foliar fertilization: mechanisms and magnitude of nutrient uptake. Proceedings of the Fluid Forum, 15-17.

Sudjana, B. (2014). Pengaruh biochar dan NPK majemuk terhadap biomas dan serapan $\mathrm{N}$ di daun tanaman jagung. Jurnal IImu Pertanian Dan Perikanan, 3(1), 63-66.

Tambunan, S., Siswanto, B., \& Handayanto, E. (2014). Biochar Terhadap Ketersediaan P Dalam Tanah Di Lahan Kering Malang Selatan. Jurnal Tanah Dan Sumbrdaya Lahan, 1(1), 85-92.

Zaylany, M. F. (2017). Pengaruh residu biochar terhadap beberapa sifat kimia tanah dan pertumbuhan tanaman jagung pada ultisol MT ke -4 (Vol. 4). UNILA 